\title{
Hemodynamic monitoring with two blood gases: "a tool that does not go out of style"
}

\section{Monitoreo hemodinámico con dos gasometrías: "Una herramienta que no pasa de moda"}

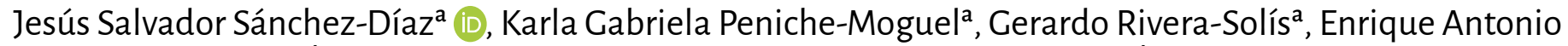 \\ Martínez-Rodríguez ${ }^{b}$, Luis Del-Carpio-Orantes ${ }^{c}$, Orlando Rubén Pérez-Nieto ${ }^{\mathrm{d}}$, Eder Iván Zamarrón-López ${ }^{\mathrm{e}}$,
} Manuel Alberto Guerrero-Gutiérrez ${ }^{f}$, Enrique Monares-Zepeda ${ }^{g}$

\author{
a Intensive Care, High Specialty Medical Unit, No. 14 Specialties Hospital, "Adolfo Ruiz Cortines" National Medical Center, Mexican Social \\ Security Institute. Veracruz, Mexico. \\ ${ }^{\mathrm{b}}$ Anesthesiology, Centro Médico ABC. Mexico City, Mexico. \\ 'Internal Medicine, Zona No.71 Ceneral Hospital, Mexican Social Security Institute. Veracruz, Mexico. \\ ${ }^{d}$ Intensive Care Unit, San Juan del Río General Hospital. Querétaro, Mexico. \\ e Intensive Care Unit, Angeles Hospital. Tampico, Mexico. \\ ${ }^{f}$ Anesthesiology, Ceneral Hospital, National La Raza Medical Center,Mexican Social Security Institute. Mexico City, Mexico. \\ ${ }^{\mathrm{g}}$ Intensive Care, ABC Medical Center. Mexico City, Mexico. \\ Correspondence: Avenida Cuauhtémoc s/n Colonia: Formando Hogar. CP 91897 Veracruz. Veracruz, México. E-mail: drsalvadorsanchezdiaz@gmail.com \\ How to cite this article: Sánchez-Díaz JS, Peniche-Moguel KG, Rivera-Solís G, Martínez-Rodríguez EA, Del-Carpio-Orantes L, Pérez-Nieto OR,et al. Hemodynamic \\ monitoring with two blood gases: "a tool that does not go out of style". Colombian Journal of Anesthesiology. 2021;49(1):e928.
}

\section{Abstract}

Hemodynamic monitoring of a critically ill patient is an indispensable tool both inside and outside intensive care; we currently have invasive, minimally invasive and non-invasive devices; however, no device has been shown to have a positive impact on the patient's evolution; arterial and venous blood gases provide information on the patient's actual microcirculatory and metabolic status and may be a hemodynamic monitoring tool. We aimed to carry out a non-systematic review of the literature of hemodynamic monitoring carried out through the variables obtained in arterial and venous blood gases. A non-systematic review of the literature was performed in the PubMed, OvidSP and ScienceDirect databases with selection of articles from 2000 to 2019. It was found that there are variables obtained in arterial and venous blood gases such as central venous oxygen saturation (SvcO2), venousto-arterial carbon dioxide pressure $(\Delta \mathrm{pv}$-aCO2), venous-to-arterial carbon dioxide pressure/arteriovenous oxygen content difference $(\Delta \mathrm{pv}$-aCO2/ $\Delta \mathrm{Ca}$ $\mathrm{vO} 2$ ) that are related to cellular oxygenation, cardiac output (CO), microcirculatory veno-arterial flow and anaerobic metabolism and allow to assess tissue perfusion status. In conclusion, the variables obtained by arterial and venous blood gases allow for non-invasive, accessible and affordable hemodynamic monitoring that can guide medical decision-making in critically ill patients.

\section{Key words}

Hemodynamic monitoring; blood gas; cardiac output; carbon dioxide; microcirculation.

\section{Resumen}

El monitoreo hemodinámico de un paciente en estado crítico es una herramienta indispensable tanto dentro como fuera de la terapia intensiva; actualmente se cuenta con dispositivos invasivos, mínimamente invasivos y no invasivos; sin embargo, ningún dispositivo ha demostrado tener impacto positivo en la evolución del paciente; la gasometría arterial y venosa proporcionan información del estado microcirculatorio y metabólico real del paciente pudiendo ser una herramienta de monitoreo hemodinámico. El objetivo de esta revisión fue realizar una revisión no sistemática de la literatura del monitoreo hemodinámico realizado mediante las variables obtenidas en la gasometría arterial y venosa. Se estudiaron las bases de datos de PubMed, OvidSP y ScienceDirect con selección de artículos del 2000 al 2019. Se encontró que hay variables obtenidas en la gasometría arterial y venosa como la saturación venosa central de oxígeno $\left(\mathrm{SvcO}_{2}\right)$, la diferencia de presión venoarterial de dióxido de carbono $(\Delta \mathrm{pv}$-aCO2), la diferencia de presión venoarterial de dióxido de carbono/diferencia del contenido arteriovenoso de oxígeno ( $\triangle \mathrm{pv}$-aCO2/ $\triangle \mathrm{Ca}-\mathrm{vO} 2)$ que están relacionadas con la oxigenación celular, con el gasto cardiaco (CC), con el flujo venoarterial microcirculatorio y con el metabolismo anaerobio que permiten realizar una valoración del estado de perfusión tisular. En conclusión, las variables obtenidas por gasometría arterial y venosa permiten realizar un monitoreo hemodinámico no invasivo, accesible y asequible que pueden guiar la toma de decisiones médicas en el paciente en estado crítico.

\section{Palabras clave}

Monitoreo hemodinámico; gasometría; gasto cardiaco; dióxido de carbono; microcirculación. 


\section{INTRODUCTION}

Monitoring, whether it be invasive, minimally invasive or non-invasive, supports clinical decision-making, hence its preeminent role in critical care. However, sufficient evidence on improved outcome data using one or another form of monitoring is still lacking (1). The most important thing will always be monere: warn or alert to prompt a decision before an event happens. The majority of the variables involved in hemodynamic monitoring hint at macrocirculation, because it appears to make sense that addressing macrohemodynamic variables should improve microcirculation (hemodynamic coherence); however, oftentimes this does not happen (2). Various techniques, methods and devices, ranging from clinical to invasive monitoring, are available to assess microcirculation abnormalities (3). In fact, across time, blood gases continue to prevail over lactate, base deficit (BD) or central venous oxygen saturation ( $\mathrm{SvcO} 2)$, because we know today that venous-to-arterial carbon dioxide pressure difference $(\Delta \mathrm{pv}$ $\mathrm{aCO} 2$ ) or venous-to-arterial carbon dioxide pressure/arteriovenous oxygen content difference $(\Delta \mathrm{pv}-\mathrm{aCO} 2 / \Delta \mathrm{Ca}-\mathrm{vO} 2)$ reflect to cardiac output (CO), microcirculatory blood flow and anaerobic metabolism, which is perhaps the true target $(4,5)$.

Clinical findings in shock are sensitive but not very specific when it comes to assessing microcirculatory blood flow, and practically of no account when it comes to anaerobic metabolism. Information provided by blood gases is a closer reflection of the true microcirculatory and metabolic status of the patient, as they show dysoxia and hemodynamic incoherence $\underline{(6,7)}$.

\section{OBJECTIVE}

To conduct a non-systematic review of the literature on hemodynamic monitoring using variables derived from arterial and venous blood gases.

\section{METHOD}

Non-systematic review of articles published between 2000 and 2020 in PubMed, OvidSP and ScienceDirect databases, using the following search terms in Spanish and English: hemodynamic monitoring, microcirculation, central venous oxygen saturation, venous-to-arterial carbon dioxide difference, venous-to-arterial carbon dioxide difference over arteriovenous oxygen content delta. Articles were selected according to title and abstract, and observational, review and original articles were included, while those that did not provide relevant information for the objective or were outside search dates were excluded. The results of this review were consistent with the authors' perspective regarding relevance, and were included if at least four authors were in agreement (Figure1).

\section{DEVELOPMENT}

\section{Central venous oxygen saturation (SvcO2)}

A central venous catheter (CVC) and an arterial line $(A L)$ are part of the devices required for patients in an intensive care unit (ICU) and samples from each of those

FIGURE 1. Flow diagram of reference search and selection.

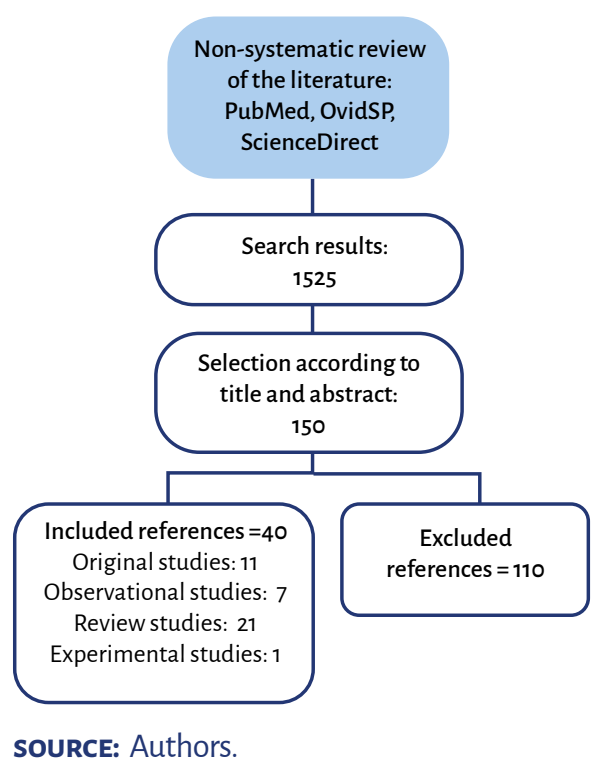

lines can provide crucial information (8). The monitor is enough to gain insight into the macrocirculatory status but, for microcirculation, central venous and arterial blood gases are an excellent choice.

In healthy individuals, $\mathrm{SvCO}_{2}$ is lower than mixed venous oxygen saturation (SvmO2) by approximately $3 \%$. This is explained by lower oxygen extraction (O2ER) from the lower body as compared to the upper body. However, this $\mathrm{SvcO}_{2} / \mathrm{SvmO}_{2}$ ratio is inverted in shock. In patients with septic shock, $\mathrm{SvcO}_{2}$ is greater than $\mathrm{SvmO}_{2}$ by up to $8 \%$, as a result of increased $\mathrm{O}_{2} \mathrm{ER}$ from the lower body (gastrointestinal tract) (9). Some studies have shown that $\mathrm{SvcO} 2$ may be an excellent proxy for $\mathrm{SvmO} 2$ values. In pathological conditions, $\mathrm{SvCO}_{2}$ rises or falls, with $70 \%$ being the normal or reference value (10).

$\mathrm{SvcO}_{2}$ is a $\mathrm{VO}_{2} / \mathrm{DO} 2$ (oxygen consumption/oxygen delivery) dependent variable: it drops when oxygen transport is low (high $\mathrm{VO} 2 / \mathrm{DO}_{2}$ ) and increases when oxygen usage is low (low VO2/DO2). When $\mathrm{DO}_{2}$ drops, compensation occurs through $\mathrm{O} 2 \mathrm{ER}$ increase but, without the right intervention, the compensation mechanism is not sufficient, the target point being $\mathrm{VO} 2$ dependence on DO2. Up to that point (cell dysoxia) $\mathrm{SvcO}_{2}$ drops in tandem with $\mathrm{DO} 2$ reduction and, from then on, anaerobic metabolism may give rise to disproportionate changes due to tissue hypoxia secondary to delays in timely and adequate interventions. Consequently, $\mathrm{SvCO}_{2}$ reliably reflects cell oxygenation status. In the context of low SvcO2, DO2 increase (in dependent zone) involves an increase in $\mathrm{VO} 2$ and, despite adequate intervention, $\mathrm{SvcO}_{2}$ remains low and will increase only after $\mathrm{VO}_{2}$ is no longer dependent on $\mathrm{DO}_{2}$ (independent zone). Low $\mathrm{ScvO}_{2}$ is not equal to $\mathrm{DO} 2$ increase (fluids, inotropes, vasopressors, beta-blockers, transfusion, oxygen) because such an intervention may have undesirable consequences. Rather, the answer is to reduce $\mathrm{VO} 2$ (pain control, sedation, mechanical ventilation, fever control, treatment for agitation, tremor or shivering control) and, consequently, perhaps the best option is a personalized intervention. High SvcO2 may be an indication of impro- 
vement, but also of inadequate $\mathrm{VO} 2$. Therefore, elevated $\mathrm{SvcO}_{2}$ does not rule out the need for therapeutic interventions and, in any case, whether it is low, normal or high, the best option is to add $\triangle \mathrm{pv}-\mathrm{aCO} 2$ and $\triangle \mathrm{pv}-\mathrm{aCO} 2 / \triangle \mathrm{Ca}-\mathrm{vO} 2$. Although lactate can be used, it is not the best option because it does not necessarily reflect tissue hypoxia or anaerobic metabolism; it should not be interpreted as a single or isolated variable, considering that there are non-hypoxic mechanisms that determine a higher reading $(11,12)$.

O2ER represents the amount (\%) of oxygen consumed (extracted) by cells from arterial blood. Non-extracted oxygen returns through the venous circulation (SvcO2) to the right cardiac cavities for reoxygenation in pulmonary circulation. In non-pathologic conditions, O2ER of 20-30\% is considered normal. Any rise in $\mathrm{O}_{2} \mathrm{ER}$ (low $\mathrm{SvcO} 2$ ) reflects increased cell metabolism (hypoxia); in contrast, a drop in O2ER (high $\mathrm{SvcO} 2)$ reflects diminished cell metabolism (hyperoxia) (13,14). Defining hypodynamic or hyperdynamic requires looking beyond the clinical condition to include cardiac index $<2.5 \mathrm{~L} / \mathrm{min} / \mathrm{m} 2, \mathrm{SvcO} 2<70 \%$ or $\mathrm{O} 2 \mathrm{ER}>30 \%$ (hypodynamic); or, conversely, cardiac index $\geq 4.0 \mathrm{~L} / \mathrm{min} / \mathrm{m} 2, \mathrm{SvcO} 2 \geq 80 \%$ or $\mathrm{O} 2 \mathrm{ER} \leq 20 \%$ (hyperdynamic) $(15,16)$ (Figure 2).

When a given $\mathrm{SvcO}_{2}$ value is analyzed, it involves the assessment of the interaction between all its determinants: 1) oxygen inflow, 2) transport 3) availability and 4) consumption (13) (Figure 3). To assess oxygen delivery and consumption in the tissues, knowledge of the following formulas is required (17):

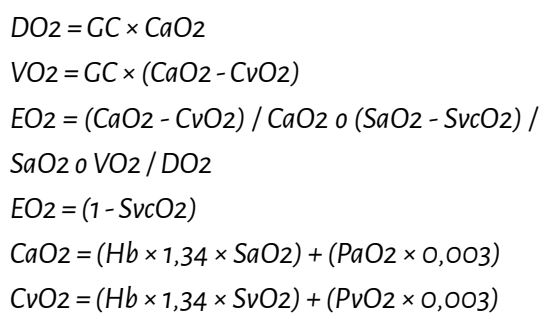

Where: $\mathrm{CaO}_{2}$ is arterial oxygen content and $\mathrm{CvO}_{2}$ is venous oxygen content.
FICURA 2. . Central venous oxygen saturation and oxygen consumption and availability ratio.

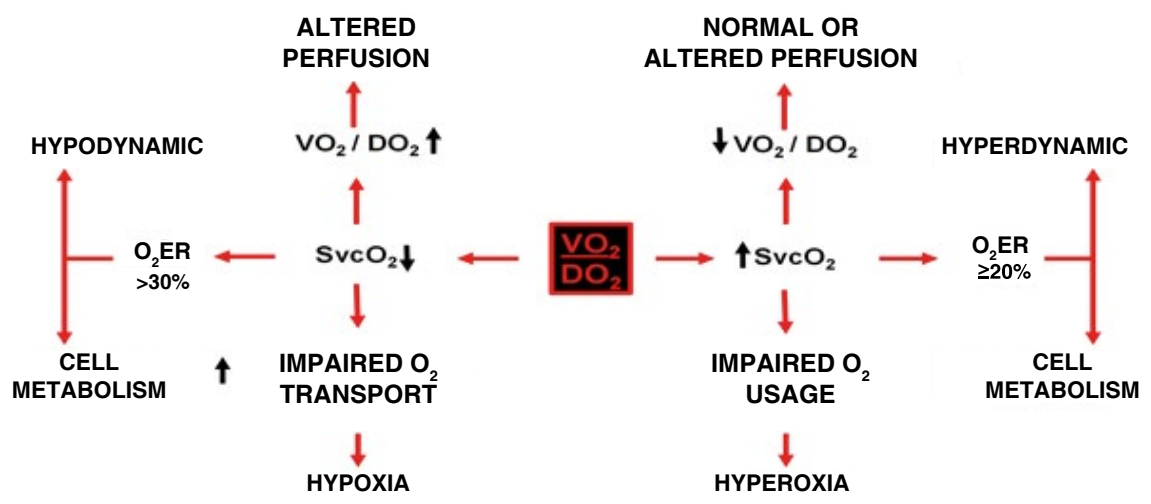

O2ER: oxygen extraction, SvcO2: central venous oxygen saturation, $\mathrm{VO} 2 / \mathrm{DO} 2$ : oxygen consumption/oxygen availability.

SOURCE: Authors.

FICURE 3. Determinantes de la saturación venosa central de oxígeno.

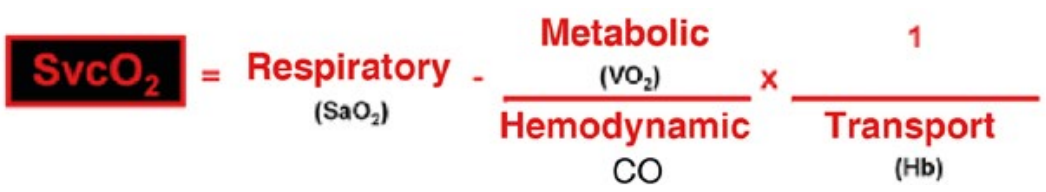

$\mathrm{CO}$ : cardiac output, $\mathrm{Hb}$ : hemoglobin, $\mathrm{SaO} 2$ : arterial oxygen saturation, $\mathrm{SvcO} 2$ : central venous oxygen saturation, $\mathrm{VO} 2$ : oxygen consumption.

SOURCE: Authors.

FICURE 4. Types of hypoxia.

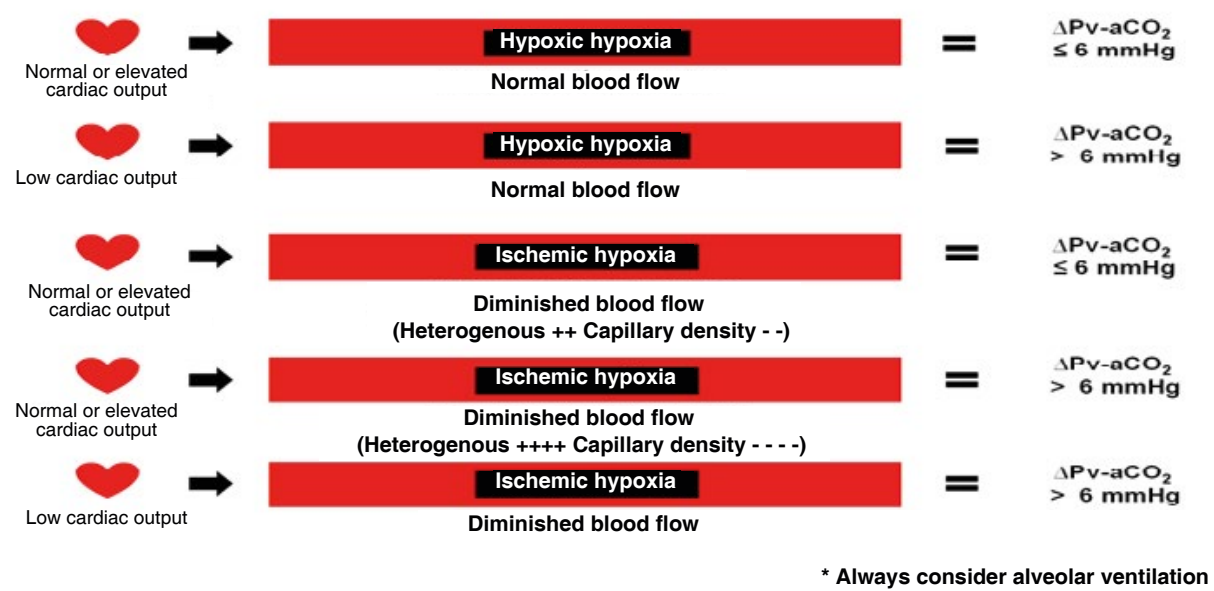

$\triangle \mathrm{pv}$-aCO2: carbon dioxide venous-to-arterial pressure delta, $\mathrm{mmHg}$ : millimeters of mercury.

SOURCE: Authors. 


\section{Venous-to-arterial carbon dioxide pressure difference $(\Delta \mathrm{p}(\mathrm{v}-\mathrm{a}) \mathrm{CO} 2)$}

Carbon dioxide $\left(\mathrm{CO}_{2}\right)$ provides even more valuable information on macro and microhemodynamics than oxygen (O2) variables. $\mathrm{CO}_{2}$ changes faster than lactate levels $(18)$. It is the metabolic product of the Krebs cycle. In the context of aerobic metabolism, increased tissue $\mathrm{CO}_{2}$ reflects greater oxidative metabolism or a higher intake of dietary carbohydrates (19). On the other hand, this increase in $\mathrm{CO}_{2}$ may be due to greater anaerobic metabolism (20).

$\triangle \mathrm{p}(\mathrm{v}-\mathrm{a}) \mathrm{CO}_{2}$ is obtained by means of one central venous and one arterial blood gas measurement and it is the difference between venous $\mathrm{pCO}_{2}$ and arterial $\mathrm{pCO}_{2}$. Its normal value ranges between 2 and 6 $\mathrm{mmHg}$ (21). Changes in $\triangle \mathrm{p}(\mathrm{v}-\mathrm{a}) \mathrm{CO}_{2}$ are determined by the degree of blood flow (perfusion) and not by the degree of tissue hypoxia. Increases in $\triangle \mathrm{p}(\mathrm{v}-\mathrm{a}) \mathrm{CO} 2$ are associated with a reduction in tissue blood flow (ischemic hypoxia) in controlled settings, as long as adequate oxygen delivery to the tissues is ensured (22). When Fick's equation is applied to $\mathrm{CO} 2$ metabolism, its clearance is found to depend on the difference between $\mathrm{CO}_{2}$ content in venous blood $\left(\mathrm{CvCO}_{2}\right)$ and $\mathrm{CO}_{2}$ in arterial blood $\left(\mathrm{CaCO}_{2}\right)$, multiplied by cardiac output or $\left(\mathrm{CvCO}_{2}-\mathrm{CaCO}_{2}\right) \times \mathrm{CO}$. Consequently, the main determinant of changes in $\triangle \mathrm{p}(\mathrm{v}-\mathrm{a}) \mathrm{CO}_{2}$ is $\mathrm{CO}$, and it is inversely proportional to it (23). Even at low CO, a patient can respond to hyperventilation with a normal or low $\triangle p(v-a) \mathrm{CO}_{2}$ (24). Therefore, $\triangle \mathrm{p}\left(\mathrm{v}\right.$-a) $\mathrm{CO}_{2}$ depends on $\mathrm{CO}, \mathrm{CvCO}_{2}$ - $\mathrm{CaCO} 2$ difference, $\mathrm{VCO} 2$, alveolar ventilation and, to a lesser extent, on microcirculatory blood flow alterations. This means that $\triangle p(v-a) \mathrm{CO}_{2}$ is a bedside surrogate of $\mathrm{CO}$ and microcirculatory blood flow. Studies have shown that, during hypoxic hypoxia (normal blood flow and lowered $\mathrm{O}_{2}$ arterial pressure), $\triangle \mathrm{p}(\mathrm{v}-\mathrm{a}) \mathrm{CO}_{2}$ is $<6 \mathrm{mmHg}$; in contrast, during ischemic hypoxia (diminished blood flow and normal $\mathrm{O} 2$ arterial pressure), $\triangle \mathrm{p}(\mathrm{v}-\mathrm{a}) \mathrm{CO}_{2}$ is $>6 \mathrm{mmHg}(25)$ (Figure 4$)$.

$\triangle \mathrm{p}(\mathrm{v}-\mathrm{a}) \mathrm{CO}_{2}$ reliably reflects $\mathrm{CO}$ variations in non-inflammatory shock states (hypovolemic, obstructive and cardiac), considering that the main change in blood flow is in the macrocirculation, unlike what happens in septic shock, where the main problem is microcirculatory blood flow, depending on capillary heterogeneity and density $(26,27)$.

\section{Venous-to-arterial carbon dioxide pressure difference/arteriovenous oxygen content delta $(\Delta \mathrm{p}(\mathrm{v}-\mathrm{a})$ $\left.\mathrm{CO}_{2} / \Delta \mathrm{C}(\mathrm{a}-\mathrm{v}) \mathrm{O}_{2}\right)$}

The relationship between $\mathrm{CO}_{2}$ production ( $\mathrm{VCO} 2$ ) and $\mathrm{O}_{2}$ consumption $\left(\mathrm{VO}_{2}\right)$ is represented by the respiratory quotient (RQ $\left.=\mathrm{V} \mathrm{CO}_{2} / \mathrm{VO}_{2}\right)$ which ranges between 0.6 and 1 , depending on individual metabolic and energy conditions. In aerobic and resting conditions, $\mathrm{VCO}_{2}$ is not greater than $\mathrm{VO}_{2}$ and, therefore, the RQ is $<1$; however, in anaerobic conditions, $\mathrm{VCO} 2$ is greater than $\mathrm{VO}_{2}$ resulting in a $\mathrm{RQ}>1 \underline{(28,29)}$. $\Delta \mathrm{p}(\mathrm{v}-\mathrm{a}) \mathrm{CO}_{2} / \Delta \mathrm{C}(\mathrm{a}-\mathrm{v}) \mathrm{O}_{2}$ is a useful surrogate of $\mathrm{RQ}=\mathrm{VCO} / \mathrm{VO} 2$ since, according to Fick's equation, $\mathrm{CO}$ is present in the numerator and the denominator and cancels out, removing the blood flow component and leaving the venous-to-arterial $\mathrm{CO}_{2}$ content difference $(\triangle \mathrm{Cv}$-aCO2$)$ and the venous-toarterial $\mathrm{O}_{2}$ content difference $\left(\triangle \mathrm{Ca}-\mathrm{VO}_{2}\right)$ as the main determinant, providing the RQ result without the need for indirect calorimetry. Because it is less invasive and offers a good correlation, $\mathrm{Ap}(\mathrm{v}-\mathrm{a}) \mathrm{CO}_{2}$ has replaced $\triangle \mathrm{Cv}-\mathrm{aCO} 2$ in obtaining $\triangle \mathrm{p}(\mathrm{v}-\mathrm{a})$ $\mathrm{CO}_{2} / \triangle \mathrm{C}(\mathrm{a}-\mathrm{v}) \mathrm{O}_{2}$ through one central venous and one arterial blood gas measurement, which allows to identify those patients in an anaerobic state $(30,31)$ (Figure 5).

$\Delta \mathrm{p}(\mathrm{v}-\mathrm{a}) \mathrm{CO}_{2} / \Delta \mathrm{C}(\mathrm{a}-\mathrm{v}) \mathrm{O}_{2}>1$ is associated with microcirculatory abnormalities that lead to $\mathrm{O}_{2} \mathrm{ER}$ reduction which, added to the drop in $\mathrm{CO}$, results in a lower $\mathrm{DO} 2$. Moreover, the increase in anaerobic $\mathrm{CO}_{2}$ favors cell dysoxia (Figure 6). If shock is reverted promptly $\Delta \mathrm{p}(\mathrm{v}-\mathrm{a}) \mathrm{CO}_{2} / \Delta \mathrm{C}(\mathrm{a}-\mathrm{v}) \mathrm{O}_{2}$ can return to values $<1$. Evidence suggests that improved microcirculatory blood flow distribution can revert anaerobic metabolism (32).

Elevated lactate does not always reflect tissue hypoxia or anaerobic metabolism and should, therefore, be used together with $\Delta \mathrm{p}(\mathrm{v}-\mathrm{a}) \mathrm{CO}_{2} / \Delta \mathrm{C}(\mathrm{a}-\mathrm{v}) \mathrm{O}_{2}$ in order to provide more accurate information at any point during patient assessment. $\Delta \mathrm{p}(\mathrm{v}-\mathrm{a})$ $\mathrm{CO}_{2} / \Delta \mathrm{C}(\mathrm{a}-\mathrm{v}) \mathrm{O}_{2}>1$ together with lactate $>2 \mathrm{mmol} / \mathrm{L}$ suggests tissue hypoxia and anaerobic metabolism with certainty, and should prompt the physician to optimize macro and microcirculation. In contrast, lactate levels $>2 \mathrm{mmol} / \mathrm{L}$ accompanied by $\quad \Delta \mathrm{p}(\mathrm{v}-\mathrm{a}) \mathrm{CO}_{2} / \Delta \mathrm{C}(\mathrm{a}-\mathrm{v}) \mathrm{O}_{2}<1$ require reassessing the origin of those levels and refraining from interpreting the result as tissue hypoxia or anaerobic metabolism (33-35). In 2016, in patients with septic shock admitted to our ICU, it was found that $\Delta \mathrm{p}(\mathrm{v}-\mathrm{a}) \mathrm{CO} 2 / \Delta \mathrm{C}(\mathrm{a}-\mathrm{v}) \mathrm{O}_{2}>1.4$, measured 24 hours after admission, increases the risk of 30-day mortality by 5.49 ( $95 \% \mathrm{Cl}$ [1.0728.09]), $p=0.04$, and is an independent predictor of mortality. On the other hand, lactate was $>2 \mathrm{mmol} / \mathrm{L}$ in $93 \%$ of the patients who did not survive while only $43 \%$ of the survivors had lactate levels > $2 \mathrm{mmol} / \mathrm{L}$, with a $\mathrm{p}$ value $=0.003(36)$. A comparison carried out in 2019 in patients with normodynamic and hyperdynamic septic shock found higher anaerobic metabolism in hyperdynamic patients compared to normodynamic patients, with a $\Delta \mathrm{p}(\mathrm{v}-\mathrm{a}) \mathrm{CO} / \Delta \mathrm{C}(\mathrm{a}-\mathrm{v}) \mathrm{O} 2$ of 2.43 vs. 1.65 , respectively; however, hyperdynamic patients had less microcirculatory blood flow alterations, with a $\Delta p(v-a) \mathrm{CO}_{2}$ of 4.77 vs. 6.17 in normodynamic patients, although this could be accounted for by elevated $\mathrm{CO}$ and not necessarily by differences in microcirculation (37).

Changes in $\mathrm{CO}_{2}$ (Haldane effect), hemoglobin concentration and tissue $\mathrm{O}_{2} \mathrm{ER}$ influence $\triangle \mathrm{pv}-\mathrm{aCO} 2$ and $\triangle \mathrm{pv}-\mathrm{aCO} 2 / \Delta \mathrm{Ca}$ $\mathrm{VO}_{2}$ despite preserved or even increased tissue perfusion. The most important counterargument has to do with the interaction on the $\mathrm{CO} 2$ dissociation curve. Another important piece of information is the ideal cutoff point for $\triangle \mathrm{pv}-\mathrm{aCO} / \Delta \mathrm{Ca}$ $\mathrm{vO}_{2}$ which is not well defined, although 
FICURE 5. Simplified respiratory quotient formula.

$$
\mathrm{RQ}=\frac{\mathrm{VCO}_{2}}{\mathrm{VO}_{2}}=\frac{\mathrm{CO} \times \Delta \mathrm{Cv}-\mathrm{aCO}_{2}}{\mathrm{CO} \times \Delta \mathrm{Ca}-\mathrm{vO}_{2}}=\frac{\mathscr{C} \times \Delta \mathrm{Pv}-\mathrm{aCO}_{2}}{\Delta \times \Delta \mathrm{Pa}-\mathrm{vO}_{2}}=\frac{\Delta \mathrm{Pv}-\mathrm{aCO}_{2}}{\Delta \mathrm{Pa}-\mathrm{vO}_{2}}=1
$$

CO: cardiac output, RQ: respiratory quotient, VCO2: carbon dioxide production, VO2: oxygen consumption, $\triangle \mathrm{CavO2}$ : arteriovenous oxygen content delta, $\triangle \mathrm{Cv}$-aCO2: venous-to-arterial carbon dioxide content delta, $\triangle \mathrm{pa}-\mathrm{vO} 2$ : arteriovenous oxygen pressure delta, $\triangle \mathrm{pv}$-aCO2: venous-to-arterial carbon dioxide pressure delta.

SOURCE: Authors.

FIGURE 6. Events that determine cell dysoxia.

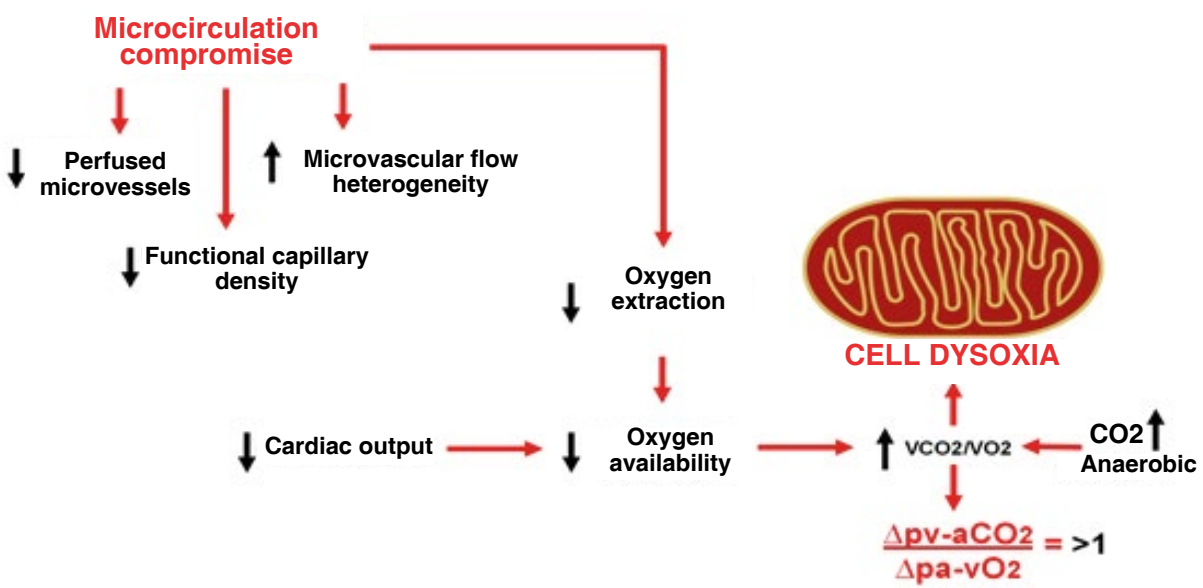

$\mathrm{CO}_{2}$ : carbon dioxide, $\mathrm{VCO} 2 / \mathrm{VO}_{2}$ : carbon dioxide production/oxygen consumption, $\triangle \mathrm{pv}-\mathrm{aCO} 2 /$ $\triangle \mathrm{Ca}$-vO2: venous-to-arterial carbon dioxide pressure delta/arteriovenous oxygen content delta.

SOURCE: Authors.

FIGURE 7. Algorithm for hemodynamic monitoring based on two blood gases.

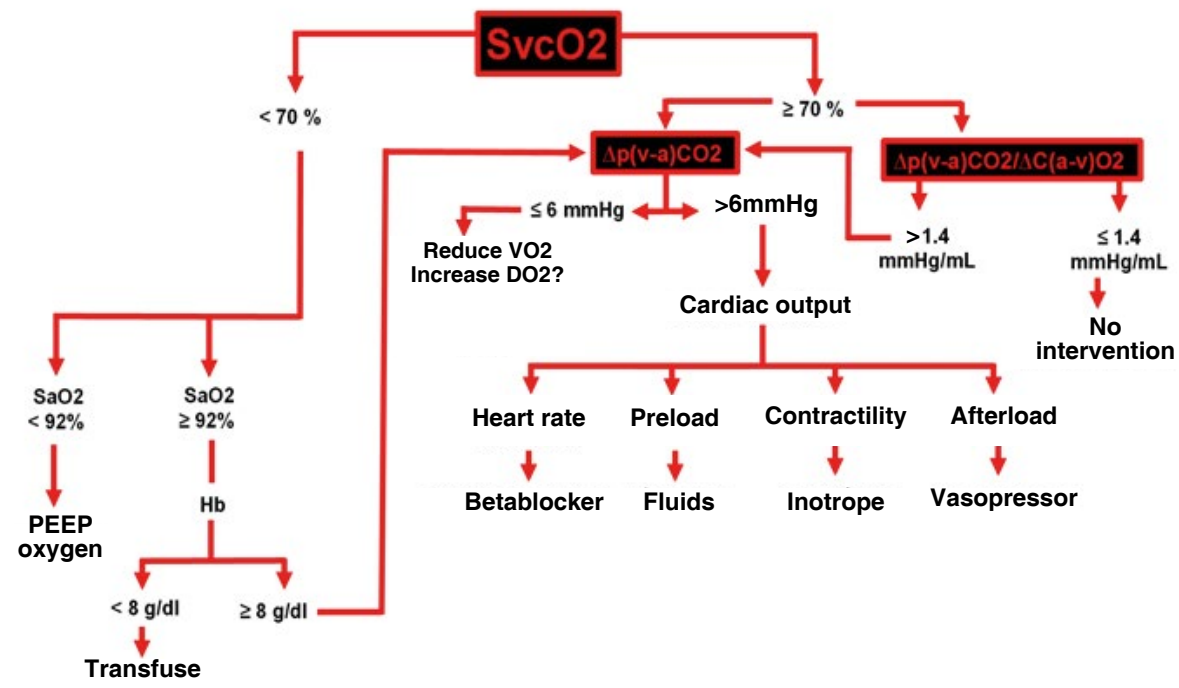

$\mathrm{G} / \mathrm{dL}$ : grams/deciliter, $\mathrm{Hb}$ : hemoglobin, $\mathrm{mmHg}$ : millimeters of mercury, $\mathrm{mmHg} / \mathrm{mL}$ : millimeters of mercury/milliliter, $\mathrm{PEEP}$ : positive end-expiratory pressure, $\mathrm{SaO} 2$ : arterial oxygen saturation, $\mathrm{SvcO} 2$ : central venous oxygen saturation, $\mathrm{VO} 2$ : oxygen consumption, $\triangle \mathrm{pv}-\mathrm{aCO}$ 2: venous-to-arterial carbon dioxide delta, $\triangle \mathrm{pv}-\mathrm{aCO} 2 / \triangle \mathrm{Ca}-\mathrm{vO} 2$ : venous-to-arterial carbón dioxide pressure delta/arteriovenous oxygen content delta.

SOURCE: Authors. it ranges between $1.4-1.68 \mathrm{mmHg} / \mathrm{mL}$ (38-40). Figure 7 shows the algorithm for hemodynamic monitoring using blood gas analysis.

\section{CONCLUSION}

Hemodynamic monitoring using blood gas analysis has been and will continue to be a bedside diagnostic tool that enables optimum and timely intervention. Whether static or dynamic, the ideal hemodynamic monitoring method does not exist. Measurement interpretations and decisionmaking will always be operator-dependent, creating advantages and disadvantages. Blood gas analyzers are readily available in any hospital, unlike sophisticated monitors. $\triangle \mathrm{pv}-\mathrm{aCO} 2$ and $\triangle \mathrm{pv}-\mathrm{aCO} 2 / \Delta \mathrm{Ca}-\mathrm{vO}_{2}$ are excellent markers or microcirculatory blood flow and anaerobic metabolism, respectively. Hemodynamic monitoring using two blood gases measurements is an option that allows to establish a diagnostic and therapeutic pathway and work on the premise of not more, not less, only what is needed.

\section{ETHICAL RESPONSIBILITIES}

\section{Human and animal protection}

The authors declare that no experiments were carried out in humans or animals for this research.

\section{Data confidentiality}

The authors declare having followed the protocols of their institution on patient data disclosure.

\section{Right to privacy and informed consent}

The authors declare that no patient data appear in this article. 


\section{ACKNOWLEDGEMENTS}

JSSD: Original idea, literature search, drafting of the development and conclusions sections, figure design and creation.

KGPM: Literature search, development and conclusions drafting.

GRS, EAMR, ORPN y MAGG: Literature search, development drafting.

DCOL: Literature search, development drafting, figure design.

EIZL: Literature search, development drafting, figure creation.

EMZ: Literature search, development drafting, figure design and creation.

\section{Funding and sponsorship}

None declared.

\section{Conflict of interest}

None declared.

\section{Appreciations}

We are grateful to the medical and nursing teams working the intensive care shifts who provided comprehensive care to this group of patients.

\section{REFERENCES}

1. Saugel B, Malbrain ML, Perel A. Hemodynamic monitoring in the era of evidence-based medicine. Crit Care. 2016;20(1):401. doi:10.1186/ s13054-016-1534-8.

2. Ince C. Hemodynamic coherence and the rationale for monitoring the microcirculation. Crit Care. 2015;19 Suppl 3:S8. doi: 10.1186/ cC14726.

3. Tafner PF, Chen FK, Rabello RF, Corrêa TD, Chaves RC, Serpa AN. Recent advances in bedside microcirculation assessment in critically ill patients. Rev Bras Ter Intensiva. 2017;29(2):23847. doi: 10.5935/0103-507X.20170033.
4. Hernández G, Boerma EC, Dubin A, Bruhn A, Koopmans M, Edul VK, et al. Severe abnormalities in microvascular perfused vessel density are associated to organ dysfunctions and mortality and can be predicted by hyperlactatemia and norepinephrine requirements in septic shock patients. J Crit Care. 2013;28:538. e9-e14. doi: 10.1016/j.jcrc.2012.11.022.

5. Ospina CA, Umaña M, Bermúdez WF, Bautista DF, Valencia JD, Madriñán H], et al. ¿Can venous-to-arterial carbon dioxide differences reflect microcirculatory alterations in patients with septic shock? Intensive Care Med 2016;42:211-21. doi: 10.1007/s00134-015-4133-2.

6. Varpula M, Tallgren M, Saukkonen K. Hemodynamic variables related to outcome in septic shock. Intensive Care Med. 2005;31(8):106671. doi: 10.1007/s00134-005-2688-z.

7. Sasko B, Butz T, Prull MW, Liebeton ], Christ M, Trappe H]. Earliest bedside assessment of hemodynamic parameters and cardiac biomarkers: Their role as predictors of adverse outcome in patients with septic shock. Int ] Med Sci. 2015;12(9):680-8. doi:10.7150/ijms.11720.

8. Velissaris D, Pierrakos C, Scolletta S, Backer D, Vincent JL. High mixed venous oxygen saturation levels do not exclude fluid responsiveness in critically ill septic patients. Crit Care. 2011;15:R177. doi:10.1186/cc10326.

9. Bloos F, Reinhart K. Venous oximetry. Intensive Care Med. 2005;31:911-3. doi:10.1007/ s00134-005-2670-9.

10. Walley KR. Use of central venous oxygen saturation to guide therapy. Am ] Respir Crit Care Med. 2011;184:514-20. doi:10.1164/rccm.201010-1584Cl.

11. Gattinoni L, Vasques F, Camporota L, Meessen ], Romitti F, Pasticci I, et al. Understanding lactatemia in human sepsis. potential impact for early management. Am J Respir Crit Care Med. 2019;200(5):582-9. doi: $10.1164 / \mathrm{rcc}-$ m.201812-2342OC.

12. Semler MW, Singer M. Deconstructing hyperlactatemia in sepsis using central venous oxygen saturation and base deficit. Am J Respir Crit Care Med. 2019;200(5):526-7. doi:10.1164/ rccm.201904-0899ED.

13. Gattinoni L, Pesenti A, Matthay M. Understanding blood gas analysis. Intensive Care Med. 2018;44(1):91-3. doi: 10.1007/s00134017-4824-y.
14. He H, Long $\mathrm{Y}$, Liu $\mathrm{D}$, Wang $\mathrm{X}$, Tang $\mathrm{B}$. The prognostic value of central venous-to-arterial $\mathrm{CO}_{2}$ difference/arterial-central venous $\mathrm{O}_{2}$ difference ratio in septic shock patients with central venous $\mathrm{O}_{2}$ saturation $\geq 80$. Shock. 2017;48(5):551-7. doi: 10.1097/ SHK.0000000000000893.

15. Dellinger R. Cardiovascular management of septic shock. Crit Care Med. 2003;31:946-55. doi: 10.1097/01.CCM.0000057403.73299.A6.

16. Edul VS, Ince C, Vázquez AR, Rubatto PN, Espinoza ED, Welsh S, et al. Similar microcirculatory alterations in patients with normodynamic and hyperdynamic septic shock. Ann Am Thorac Soc. 2016;13(2):240-7. doi: 10.1513/ AnnalsATS.201509-6060C.

17. Tánczos K, Molnár Z. The oxygen supply-demand balance: a monitoring challenge. Best Pract Res Clin Anaesthesiol. 2013;27(2):201-7. doi: 10.1016/j.bpa.2013.06.001.

18. Lippi G, Fontana R, Avanzini P, Sandei F, Ippolito L. Influence of spurious hemolysis on blood gas analysis. Clin Chem Lab Med. 2013;51(8):1651-4. doi: 10.1515/cclm-2012-0802.

19. Saludes P, Proença L, Gruartmoner G, Enseñat L, Pérez-Madrigal A, Espinal C et al. Central venous-to-arterial carbon dioxide difference and the effect of venous hyperoxia: A limiting factor, or an additional marker of severity in shock?. J Clin Monit Comput. 2017;31(6):1203-11. doi:10.1007/s10877-016-9954-1.

20. Ospina GA, Umaña M, Bermúdez W, Bautista DF, Hernández G, Bruhn A, et al. Combination of arterial lactate levels and venous-arterial $\mathrm{CO}_{2}$ to arterial-venous $\mathrm{O}_{2}$ content difference ratio as markers of resuscitation in patients with septic shock. Intensive Care Med. 2015;41(5):796-805. doi: 10.1007/s00134-0153720-6.

21. Ospina-Tascón G, Madriñán H. Combination of $\mathrm{O}_{2}$ and $\mathrm{CO}_{2}$-derived variables to detect tissue hypoxia in the critically ill patient. ] Thorac Dis. 2019;S1544-50. doi: 10.21037/ itd.2019.03.52.

22. Mallat ], Vallet B. Difference in venous-arterial carbon dioxide in septic shock. Minerva Anestesiol. 2015;81(4):419-25.

23. Lamia B, Monnet X, Teboul JL. Meaning of arterio-venous $\mathrm{PCO} 2$ difference in circulatory shock. Minerva Anestesiol. 2006;72(6):597-604. 
24. Diaztagle-Fernández J], Rodríguez-Murcia JC, Sprockel-Díaz ]. Venous-to-arterial carbon dioxide difference in the resuscitation of patients with severe sepsis and septic shock: a systematic review. Med Intensiva. 2017;41(7):401-10. doi: 10.1016/j.medin.2017.03.008.

25. Waldauf P, Jiroutkova K, Duska F. Using $\mathrm{pCO} 2$ Gap in the differential diagnosis of hyperlactatemia outside the context of sepsis: a physiological review and case series. Crit Care Res Pract. 2019:5364503. doi: 10.1155/2019/5364503.

26. Vallet B, Teboul JL, Cain S, Curtis S. Venoarterial $\mathrm{CO}_{2}$ difference during regional ischemic or hypoxic hypoxia. ] Appl Physiol. 2000;89(4):1317-21. doi: 10.1152/jappl.2000.89.4.1317.

27. Van Beest PA, Lont MC, Holman ND, Loef B, Kuiper MA, Boerma EC. Central venous-arterial $\mathrm{pCO} 2$ difference as a tool in resuscitation of septic patients. Intensive Care Med. 2013;39(6):1034-9. doi: 10.1007/s00134-0132888-x.

28. De Backer D, Ospina G, Salgado D, Favory R, Creteur ], Vincent JL. Monitoring the microcirculation in the critically ill patient: current methods and future approaches. Intensive Care Med. 2010;36(11):1813-25. doi: 10.1007/ so0134-010-2005-3.

29. Mekontso A, Castelain V, Anguel N, Bahloul $M$, Schauvliege F, Richard C, et al. Combination of venoarterial $\mathrm{PCO} 2$ difference with arteriovenous $\mathrm{O} 2$ content difference to detect anaerobic metabolism in patients. Intensive Care Med. 2002;28(3):272-7. doi: 10.1007/ s00134-002-1215-8.

30. Ospina GA, Hernández G, Cecconi M. Understanding the venous-arterial $\mathrm{CO}_{2}$ to arterial-venous $\mathrm{O} 2$ content difference ratio. Intensive Care Med. 2016;42(11):1801-4. doi: 10.1007/s00134-016-4233-7.

31. Ospina CA, Calderón Tapia LE. Venous-arterial $\mathrm{CO}_{2}$ to arterial-venous $\mathrm{O} 2$ differences: A physiological meaning debate. ] Crit Care. 2018;48:443-4. doi: 10.1016/j.jcrc.2018.09.030.

32. Mallat ], Lemyze $M$, Tronchon L, Vallet B, Thevenin $D$. Use of venous-to-arterial carbon dioxide tension difference to guide resuscitation therapy in septic shock. World ] Crit Care Med. 2016;5:47-56. doi: 10.5492/wjccm.v5.11.47.

33. Goldman D, Bateman RM, Ellis CG. Effect of decreased $\mathrm{O}_{2}$ supply on skeletal muscle oxygenation and $\mathrm{O} 2$ consumption during sepsis: role of heterogeneous capillary spacing and blood flow. Am J Physiol Heart Circ Physiol. 2016;290:H2277-85. doi: 10.1152/ ajpheart.00547.2005.

34. He HW, Liu DW, Long Y, Wang XT. High central venous-to-arterial $\mathrm{CO}_{2}$ difference/ arterial-central venous $\mathrm{O}_{2}$ difference ratio is associated with poor lactate clearance in septic patients after resuscitation. ] Crit Care. 2016;31(1):76-81. doi: 10.1016/j. jcrc.2015.10.017.

35. He HW, Liu DW, Ince C. Understanding elevated $\mathrm{Pv}-\mathrm{aCO} 2$ gap and $\mathrm{Pv}-\mathrm{aCO} 2 / \mathrm{Ca}-\mathrm{vO} 2$ ratio in venous hyperoxia condition. ] Clin Monit Comput 2017;31:1321-3. doi: 10.1007/s10877017-0005-3.

36. Rivera SC, Sánchez DJS, Martínez REA, García MRC, Huanca PJM, Calyeca SMV. Clasificación clínica de la perfusión tisular en pacientes con choque séptico basada en la saturación venosa central de oxígeno (SvcO2) y la diferencia enoarterial de dióxido de carbono entre el contenido arteriovenoso de oxígeno $(\triangle \mathrm{P}(\mathrm{v}-\mathrm{a})$ $\mathrm{CO} 2 / \mathrm{C}(\mathrm{a}-\mathrm{v}) \mathrm{O} 2)$. Rev Asoc Mex Med Crit y Ter Int. 2016;30(5):283-9.

37. Pascual ES, Sánchez DJS, Peniche MKG, Martínez REA, Villegas DJE, Calyeca SMV. Evaluación de la perfusión tisular en pacientes con choque séptico normodinámico versus hiperdinámico. Rev Asoc Mex Med Crit y Ter Int 2018;32(6). doi: 10.35366/Tl186C.

38. He HW, Liu DW. Central venous-to-arterial $\mathrm{CO} 2$ difference/arterial-central venous $\mathrm{O}_{2}$ difference ratio: An experimental model or a bedside clinical tool? ] Crit Care. 2016;35:21920. doi: 10.1016/j.jcrc.2016.05.009.

39. Yuan S, He H, Long L. Interpretation of venous-to-arterial carbon dioxide difference in the resuscitation of septic shock patients. J Thorac Dis. 2019;S1538-43. doi: 10.21037/ jtd.2019.02.79.

40. Gavelli F, Teboul JL, Monnet X. How can $\mathrm{CO} 2$-derived indices guide resuscitation in critically ill patients?. J Thorac Dis. 2019;S152837. doi: 10.21037/jtd.2019.07.10. 